Jakub ŚLĘCZEK ${ }^{1,2}$, Filip ZABOROWSKI ${ }^{2}$

${ }^{I}$ Air Force Institute of Technology (Instytut Techniczny Wojsk Lotniczych)

${ }^{2}$ Gdańsk University of Technology (Politechnika Gdańska)

\title{
REACTION WHEEL CONTROL SYSTEM FOR CUBESAT NANOSATELLITE
}

\section{Układ sterowania nanosatelity typu CubeSat za pomocą kół reakcyjnych}

\begin{abstract}
Nanosatellites, although originally developed for educational purposes, are increasingly being used for commercial sense. Continuous increase in the application and use means that they require continuous improvement of performance to cope with new challenges. An important issue is the control of the position of the satellite sufficiently accurate and fast to enable it to efficiently carry out its mission. This paper includes a project consisting of a modelled test system and a presented method of control with simulation. Then, the obtained results and resulting conclusions are discussed.
\end{abstract}

Keywords: nanosatellite, reaction wheels, control system

Streszczenie: Nanosatelity, chociaż pierwotnie stworzone do celów edukacyjnych, coraz częściej sa używane do celów komercyjnych. Ciagly wzrost ich zastosowania oraz użytkowania sprawia, że wymagają one ciagłej poprawy osiagów aby mogły poradzić sobie z nowymi wyzwaniami. Ważnym polem na tym tle jest sterowanie położeniem satelity na tyle dokładne i szybkie aby mógt on efektywnie wykonywać swoja misję. W tej pracy zawarty jest projekt składający się z zamodelowanego układu testowego oraz przedstawiony sposób sterowania razem z symulacją. Następnie omówione sq osiągnięte wyniki i konkluzje z nich wynikajace.

Słowa kluczowe: nanosatelita, koła reakcyjne, system sterowania 


\section{Introduction}

Attitude control of artificial satellites in space is a key issue, and without it, the operation of many currently operating space technology services would not be possible. Miniature CubeSat satellites are mainly used for educational applications, conducting miniaturized experiments, earth observation, and amateur radio [1,7]. The nanosatellites also enable testing the operation of individual components of larger devices in space conditions.

There are many approaches to the problem of controlling the position of a satellite depending on the data that can be used to determine the attitude. It is possible to control the position without the use of gyroscopes and without taking into account the dynamics of the satellite [2]. Another approach is to use algorithms based on images of the Earth [4].

Despite many advances in satellite position control, there is still a place for improvement. One of such elements is to compensate for the position error caused by complex rotational movement causing coning motion [9].

The aim of this work is to develop a nanosatellite test rig by creating its model and simulating the results attitude control subjected to disturbances resulting from gravitational force. The nanosatellite will be controlled by three reaction wheels arranged orthogonally to each other.

\section{Methods}

\subsection{Dynamics}

Satellite dynamics can be described by the given equations [8]:

$$
\begin{aligned}
& T_{d x}+T_{c x}=I_{x} \ddot{\varphi} \\
& T_{d y}+T_{c y}=I_{y} \ddot{\theta} \\
& T_{d z}+T_{c z}=I_{z} \ddot{\psi}
\end{aligned}
$$

$T$ is torque, index $d$ refers to external disturbances acting on the satellite, index $c$ refers to the control torque generated by reaction wheels in the $\mathrm{x}, \mathrm{y}$ and $\mathrm{z}$ axes (fig. 1). $\mathrm{I}$ is the satellite's inertia, and the index relates to the axis relative to which it is measured.

According to [8], the rotation of a satellite about one axis can be calculated by double integration. Applying the Laplace transform on equations (1), (2) and (3), we obtain the function, where torque is the input data, and the position is the output:

$$
\begin{aligned}
& \frac{\varphi(s)}{T_{x}(s)}=\frac{1}{I_{x} s^{2}} \\
& \frac{\theta(s)}{T_{y}(s)}=\frac{1}{I_{y} s^{2}}
\end{aligned}
$$




$$
\frac{\psi(s)}{T_{Z}(s)}=\frac{1}{I_{z} s^{2}}
$$

where $T$ is a sum of control torque and disturbance torque.

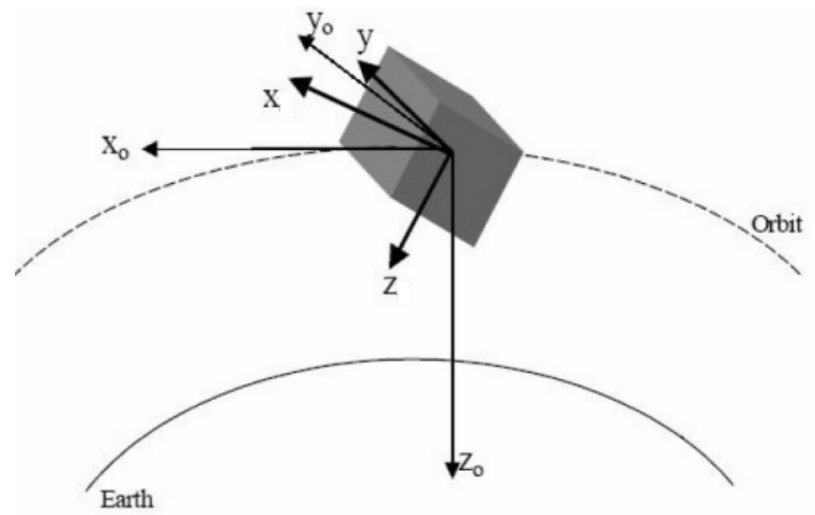

Fig. 1. Orbit frame and body frame [3]

\subsection{Disturbances}

Satellites are exposed to several forces in space. The mentioned forces are gravity, aerodynamic drag, solar radiation and the magnetic field. The external disturbing forces are negligible in comparison with control torque from the reaction wheels. In this system, only interference due to gravity will be taken into consideration. This is caused by the fact that unbalanced satellite results in small differences in the gravitational pull of its ends.

$$
T_{d}=T_{g g}
$$

$T_{d}$ is disturbing torque and $T_{g g}$ is gravitational torque.

Analytical gravitational torque can be computed as follows [5]:

$$
T_{g g}=3 \omega_{o}^{2} c_{3} \times I c_{3}
$$

$I$ is the satellite inertia matrix and $\omega_{o}$ represents the angular velocity of the orbit system around its $\mathrm{y}_{\mathrm{o}}$ axis. $c_{3}$ is a unit vector pointing towards the nadir ( $\mathrm{z}_{\mathrm{o}}$ axis). The angular velocity can be obtained by the following equation [5]:

$$
\omega_{o}^{2}=\frac{\mu}{r_{c}^{3}}
$$


where $\mu=3.986 \cdot \frac{10^{14} m^{3}}{s^{2}}$ is gravitational constant and $r_{c}$ is a distance between satellite center of mass and Earth center of mass.

\subsection{Model}

The satellite model (fig. 2) was designed in Autodesk Inventor as an assembly element consisting of individually designed parts. The main emphasis during modeling of the structure was placed on the possibility of adapting the structure to various solutions of the control system, hence a greater number of mounting holes for motors assemble.

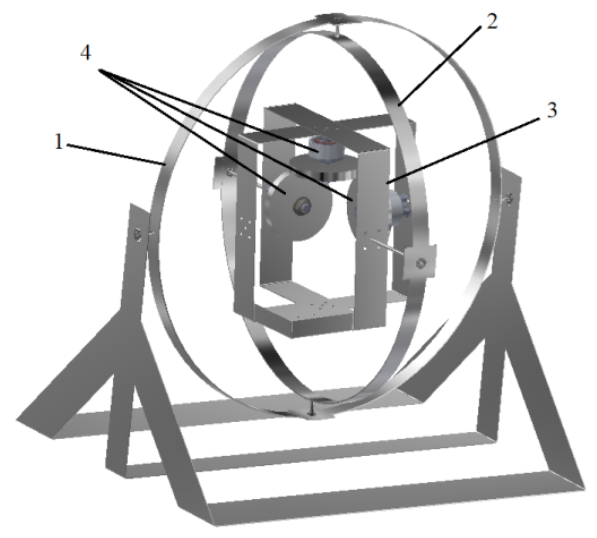

Fig. 2. Visualization of the entire testing rig with motors and reaction wheels: 1 - outer rim, 2 -inner rim, 3 - model frame, 4 - DC motor and reaction wheel for each axis

Electronic elements have been added to the visualization, shown in fig. 1.The model drivers are GEPRC SPEEDX GR1507 BLDC motors. Reaction wheels with a width of 5 $\mathrm{mm}$ and a $20 \mathrm{~mm}$ radius are mounted on the motor shafts. Which, if made of aluminium, will have a moment of inertia equal to $3.392 \mathrm{~kg} * \mathrm{~mm} 2$ in the axis parallel to the motor shaft.

The model is intended to be made of 6061 aluminium alloy, and computation was made for this material. The moments of inertia acting on the satellite dynamics and control system are shown in tab. 1. The moments of inertia were computed in respect to the axis of rotation of the model. To simplify the model inertia computation, it was assumed that every element not lying on the rotation axis was treated as a particle point having its position in the geometrical center of each element. In case when the elements were lying on the rotation axis, their moments of inertia were computed for simple objects with geometric symmetry. The second assumption was motor mass distribution, which is the same in all of its volume. The moment of inertia of the reaction wheel with respect to its rotation axis is zero. 
Table 1

Computed values of the moments of inertia for the reaction wheels and motors

\begin{tabular}{|c|c|c|c|c|}
\hline Name & Mass [kg] & Axis & $\begin{array}{c}\text { Distance to } \\
\text { rotation axis }[\mathrm{mm}]\end{array}$ & $\begin{array}{c}\text { Moment of inertia } \\
{\left[\mathrm{kg} \times \mathrm{mm}^{2}\right]}\end{array}$ \\
\hline \multirow{3}{*}{$\begin{array}{l}\text { Reaction wheel on } \\
\qquad \mathrm{X} \text { axis }\end{array}$} & \multirow{3}{*}{0.017} & $\mathrm{x}$ & 0 & 0.0 \\
\hline & & $\mathrm{y}$ & 27.5 & 12.9 \\
\hline & & $\mathrm{z}$ & 27.5 & 12.9 \\
\hline \multirow{3}{*}{$\begin{array}{l}\text { Reaction wheel on } \\
\text { Y axis }\end{array}$} & \multirow{3}{*}{0.017} & $\mathrm{x}$ & 27.5 & 12.9 \\
\hline & & $\mathrm{y}$ & 0 & 0.0 \\
\hline & & $\mathrm{z}$ & 27.5 & 12.9 \\
\hline \multirow{3}{*}{$\begin{array}{l}\text { Reaction wheel on } \\
\qquad \mathrm{Z} \text { axis }\end{array}$} & \multirow{3}{*}{0.017} & $\mathrm{x}$ & 27.5 & 12.9 \\
\hline & & $\mathrm{y}$ & 27.5 & 12.9 \\
\hline & & $\mathrm{z}$ & 0 & 0.0 \\
\hline \multirow{3}{*}{ Motor on $\mathrm{X}$ axis } & \multirow{3}{*}{0.015} & $\mathrm{x}$ & 0 & 0.6 \\
\hline & & $\mathrm{y}$ & 40 & 24.0 \\
\hline & & $\mathrm{z}$ & 40 & 24.0 \\
\hline \multirow{3}{*}{ Motor on $\mathrm{Y}$ axis } & \multirow{3}{*}{0.015} & $\mathrm{x}$ & 40 & 24.0 \\
\hline & & $\mathrm{y}$ & 0 & 0.6 \\
\hline & & $\mathrm{z}$ & 40 & 24.0 \\
\hline \multirow{3}{*}{ Motor on $\mathrm{Z}$ axis } & \multirow{3}{*}{0.015} & $\mathrm{x}$ & 40 & 24.0 \\
\hline & & $\mathrm{y}$ & 40 & 24.0 \\
\hline & & $\mathrm{z}$ & 0 & 0.6 \\
\hline \multirow{3}{*}{$\begin{array}{l}\text { Electronics } \\
\text { (example) }\end{array}$} & \multirow{3}{*}{0.1} & $\mathrm{x}$ & 35 & 122.5 \\
\hline & & $\mathrm{y}$ & 35 & 122.5 \\
\hline & & $\mathrm{z}$ & 35 & 122.5 \\
\hline
\end{tabular}

Table 2

Moments of inertia of structural elements

\begin{tabular}{||c|c|c|l||}
\hline Name & Mass [kg] & Axis & Moment of inertia $\left[\mathbf{k g} \times \mathbf{m m}^{2}\right]$ \\
\hline \multirow{3}{*}{ Model frame } & \multirow{3}{*}{0.023} & $\mathrm{x}$ & 40.1 \\
\cline { 3 - 4 } & & $\mathrm{y}$ & 62.1 \\
\cline { 3 - 4 } & \multirow{3}{*}{0.015} & $\mathrm{z}$ & 58.6 \\
\cline { 3 - 4 } & & $\mathrm{x}$ & 93 \\
\cline { 3 - 4 } & & $\mathrm{y}$ & no rotation \\
\hline \multirow{3}{*}{ Outer suspension rim } & \multirow{3}{*}{0.015} & $\mathrm{x}$ & no rotation \\
\hline & & $\mathrm{y}$ & 135 \\
\cline { 3 - 4 } & & $\mathrm{z}$ & 71 \\
\hline
\end{tabular}


It can be seen that the simulation will introduce significant distortion to the operation of the whole system compared to the target environment; however, a typical satellite will also not have the same moment in each axis, it will not be symmetrical to the center.

\subsection{System dynamics}

The description of the system is the combination of the actuator mechanism and the dynamics of the satellite. In this section system, dynamics is presented for rotation in y axis, but the method is the same for all axes. The actuator and satellite blocks are in series configuration, hence there is [6]:

$$
\frac{\theta(s)}{T_{C}(s)}=\frac{\frac{K}{R \cdot I_{s}}}{s^{2}\left(s+\frac{K}{R}\right)}
$$

Where $T_{C}$ is a command torque, $\mathrm{K}$ is a system gain, $\mathrm{I}_{\mathrm{s}}$ refers to satellite moment of inertia and $\mathrm{R}$ is input resistance of actuator.

It is possible to apply equation 8 if the following requirement is met [6]:

$$
K \gg \frac{K_{V} \cdot K_{T}}{I_{W}}
$$

$\mathrm{K}_{\mathrm{V}}$ is an EMF constant of the actuator, $\mathrm{K}_{\mathrm{T}}$ denotes torque constant of the actuator and $\mathrm{I}_{\mathrm{W}}$ is a moment of inertia of the reaction wheel. It was found that transfer function gain $K$ should be much greater than 0.95 .

To optimize the response of the system, proportional-integral-derivative regulator has been applied.

The simplified model can be applied only under specific conditions:

- Measurement noises in position and angular velocity sensors are negligibly small;

- Change of attitude commands are small;

- Sliding friction at the reaction wheel assembly place is negligibly low;

- At the reaction wheel assembly place, torque and speed are not saturated.

- The inner control optimization is based on the following criteria:

- Dumping factor $\zeta \geq 1$

- Phase margin $180^{\circ}>P$. $M>45$

- System bandwidth $\omega_{b}=3.33 \mathrm{~Hz}$

System dynamics was computed based on motors, reaction wheels and satellite parameters (tab. 3). Regulator gains were computed in MATLAB using SISOTool (tab. 4), and simulations were made in Simulink. 
Table 3

Parameters used in system dynamics

\begin{tabular}{|l|l|l|l|l|}
\hline Parameter & Description & x axis & y axis & z axis \\
\hline $\mathrm{R}$ & Input resistance $[\Omega]$ & 22 & 22 & 22 \\
\hline $\mathrm{K}_{\mathrm{T}}$ & Torque constant $[\mathrm{Nm} / \mathrm{A}]$ & $3.4 \times 10^{-3}$ & $3.4 \times 10^{-3}$ & $3.4 \times 10^{-3}$ \\
\hline $\mathrm{K}_{\mathrm{V}}$ & EMF constant $[\mathrm{V} / \mathrm{rpm}]$ & $357 \times 10^{-6}$ & $357 \times 10^{-6}$ & $357 \times 10^{-6}$ \\
\hline $\mathrm{I}_{\mathrm{W}}$ & $\begin{array}{l}\text { Reaction wheel moment of inertia } \\
{\left[\mathrm{kg} \times \mathrm{m}^{2}\right]}\end{array}$ & $13 \times 10^{-6}$ & $13 \times 10^{-6}$ & $13 \times 10^{-6}$ \\
\hline $\mathrm{I}_{\mathrm{S}}$ & $\begin{array}{l}\text { Satellite moment of inertia } \\
{\left[\mathrm{kg} \times \mathrm{m}^{2}\right]}\end{array}$ & $465 \times 10^{-6}$ & $330 \times 10^{-6}$ & $255 \times 10^{-6}$ \\
\hline
\end{tabular}

\section{Results}

The final control system includes two feedback loops. The inner loop is regulated by the derivative controller and the outer loop by the proportional-integral controller. It is a well-known PID controller where the integrator and derivative work in parallel. The individual values of the controller terms are shown in tab. 4 .

Table 4

\section{Optimized PID gains}

\begin{tabular}{||l|l|l|l||}
\hline PID regulator term & $\mathbf{x}$ axis & y axis & $\mathbf{z}$ axis \\
\hline $\mathrm{Kp}$ & 0.97922 & 0.63505 & 0.71523 \\
\hline $\mathrm{Kd}$ & 1 & 0.03072 & 0.65861 \\
\hline $\mathrm{Ki}$ & 0.59499 & 0.18272 & 0.25884 \\
\hline
\end{tabular}

The performance of the closed-loop system improved significantly after applying the regulation to all three axes of the satellite. First of all, the responsiveness has increased, which is of particular importance. The initial single proportional gain system was far too slow compared to the tuned system. Responses to unit step and unit response are shown in the plots below. The quick reaction of the system takes place at the cost of a slight overshoot. The amplitude and phase margin decreased significantly but remained within the acceptable range. 

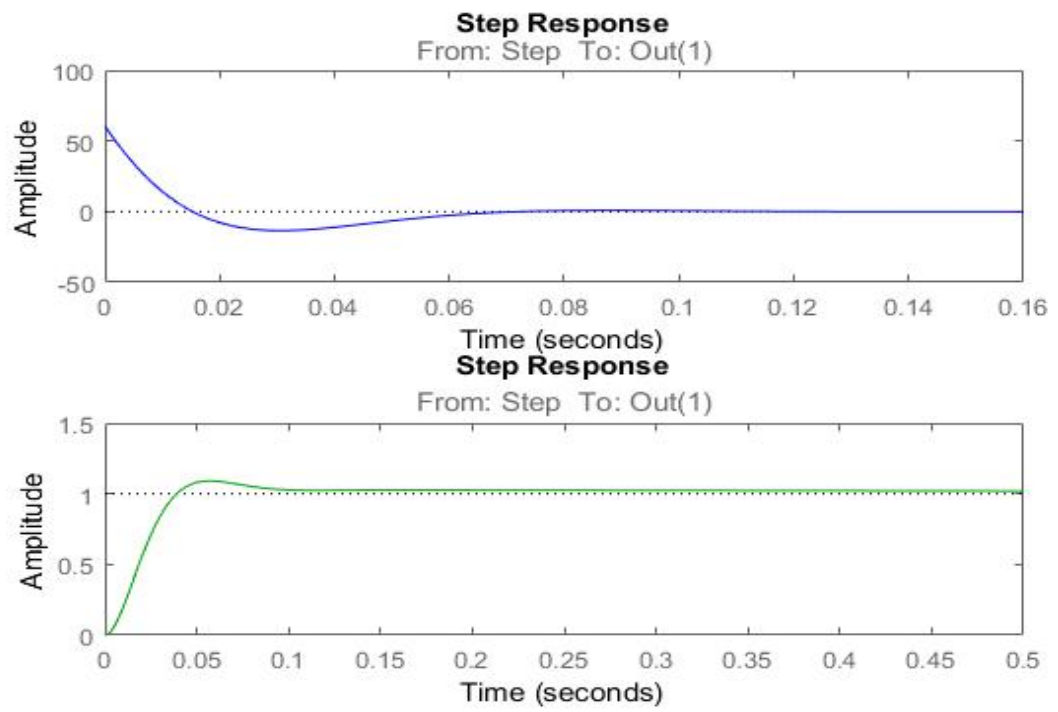

Fig. 3. Step response at the controller output and at the system output in $\mathrm{X}$ axis

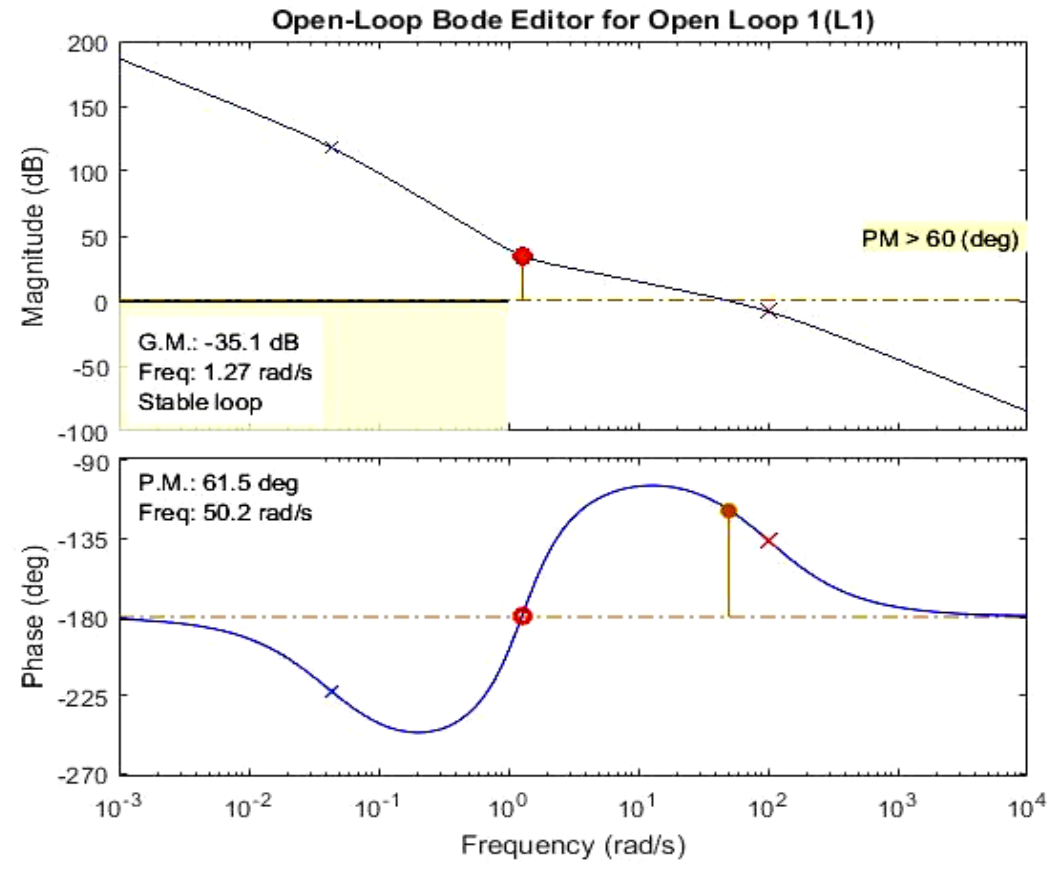

Fig. 4. Bode plot for $\mathrm{X}$ axis control system 

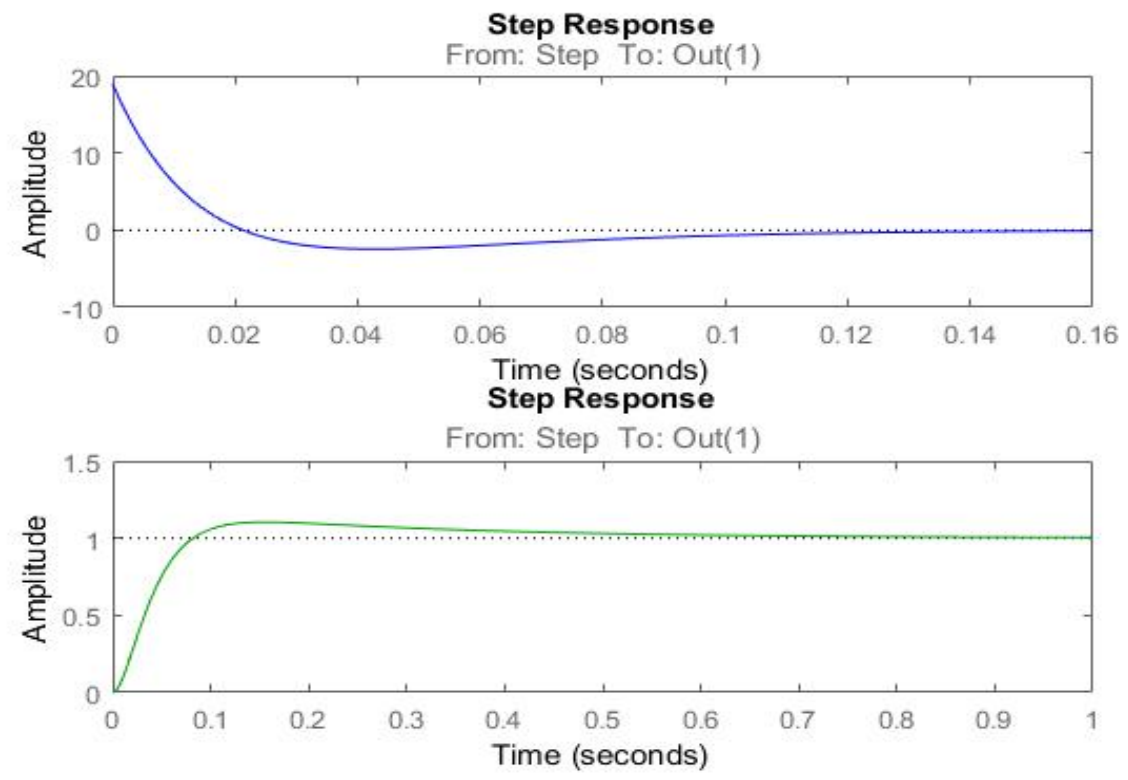

Fig. 5. Step response at the controller output and at the system output in $\mathrm{Y}$ axis
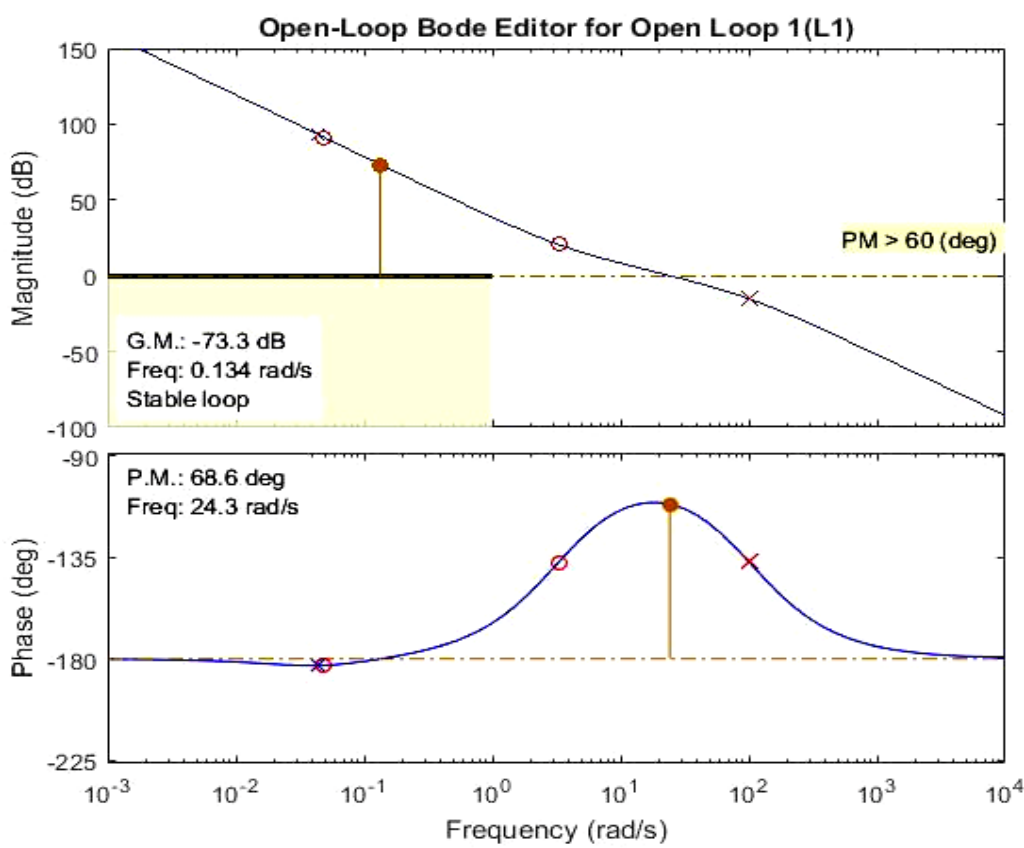

Fig. 6. Bode plot for Y axis control system 

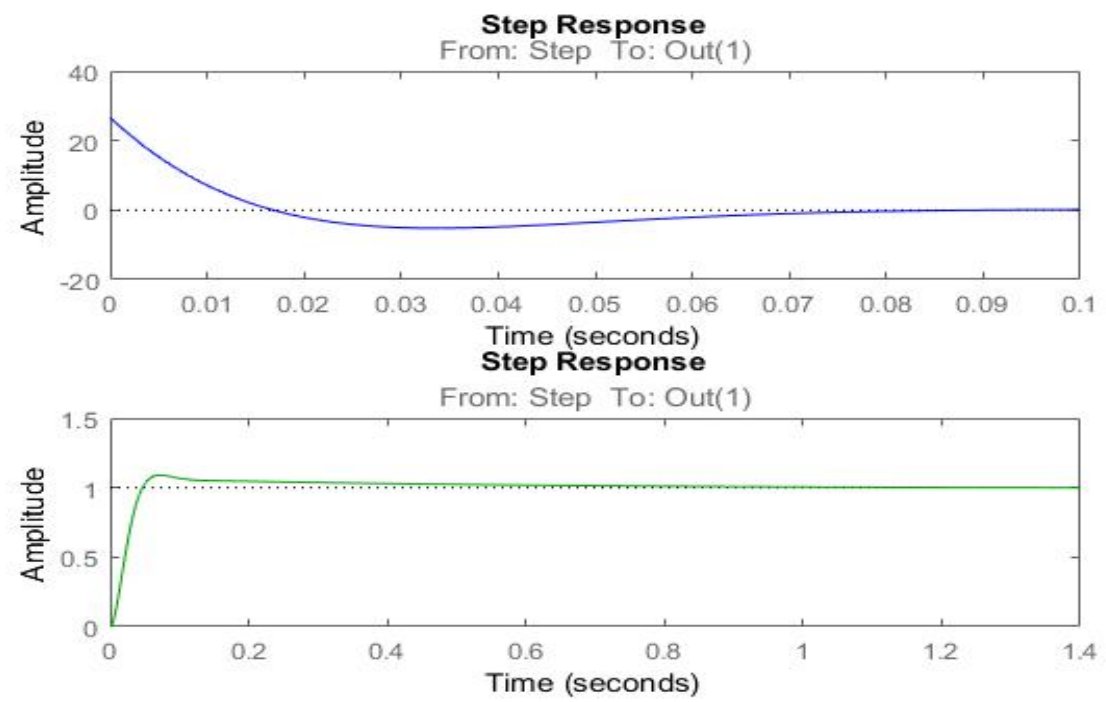

Fig. 7. Step response at the controller output and at the system output in $Z$ axis

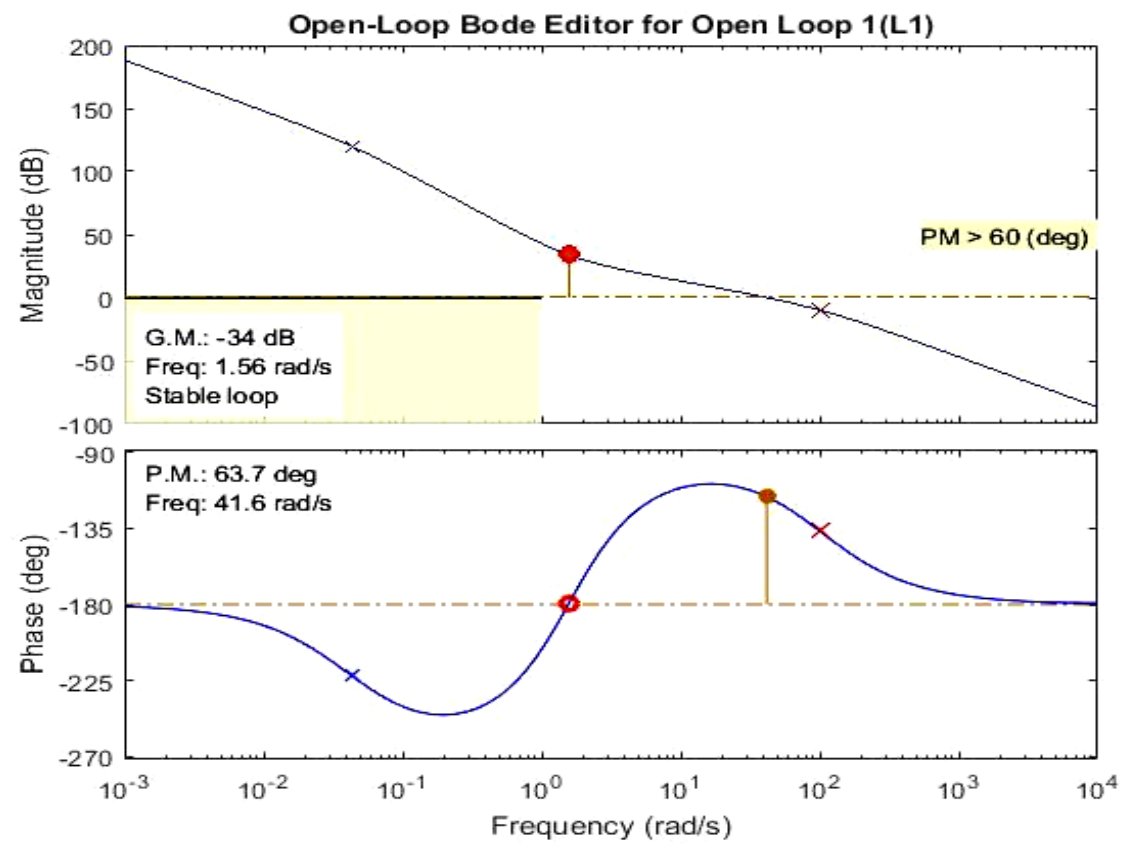

Fig. 8. Bode plot for $Z$ axis control system 


\section{Conclusions}

A test rig was designed as a system of three interconnected rims representing 3 axes of rotation. During the simulation tests, it was confirmed that the model accurately simulates the satellite's dynamics and ensures the satellite's rotation in three degrees of freedom. The exception is setting the two rims in parallel, which may block rotation in one of the axes, but the chance of achieving such a configuration is not high. This should not be a significant problem as it can be prevented with proper control.

The designed control system, after testing it on a satellite model, works in a predictable manner. Research has shown that the system is stable and tends to nearly zero steady-state error. The overshoot is very low, at the steady-state error level. Also, there are no oscillations when the system reaches its set point. From the results obtained in the simulation, it can be observed that the PID controller works well in the designed control system. However, it cannot be stated whether the designed system is the most optimal solution for controlling nanosatellites.

\section{References}

1. Camps A.: Nanosatellites and Applications to Commercial and Scientific Missions, Satellites Missions and Technologies Geocsiences, Barcelona 2019.

2. Hajiyev Ch., Cilden Guler D.:Review on gyroless attitude determination methods for small satellites, Progress in Aerospace Sciences, Istambul 2017.

3. Karatas S.: LEO Satellites: Dynamics Modelling, Simulations and some Nonlinear Attitude Control Techniques. Master's thesis, Middle East Technical University 2006.

4. Kouyama T. Kanemura A., Kato S., Imamoglu N., Fukuhara T.: Satellite Attitude Determination and Map Projection Based on Robust Image Matching, Remote sensing, Tokyo 2017.

5. Kristiansen R.. Attitude Control Of a Microsatellite. Master Thesis, Department of Engineering Cybernetics, NTNU, 2000.

6. Molina J.: Attitude Control Model for CubeSats, IAA-BR-07-01, Guatemala 2016.

7. Nagel G. W., Novo E. M. L. d., Kampel M.: Nanosatellites applied to optical Earth observation: a review, Revista Ambiente e Angua, Sao Jose dos Compos 2020.

8. Sidi M. J.: Linearized Attitude Dynamics Equations of Motion, Cambridge University Press, New York, 1997

9. Zhang S., Su Z., Li X.: Real-Time Angular Motion Decoupling and Attitude Updating Method of Spinning Bodies Assisted by Satellite Navigation Data, IEEE Access, Beijing 2019. 